\title{
System Dynamic Simulation of Salacca-Pondoh's Business as Usual in Sleman District, Yogyakarta Province, Indonesia
}

\author{
Mohammad Prasanto Bimantio ${ }^{*}$, Alva Edy Tontowi², Anna Maria Sri Asih ${ }^{2}$
}

\begin{abstract}
Horticultural crops production in Sleman District was dominated by salacca-pondoh, which reached 73-kiloton total production in 2016. This number was over 98\% of the total salacca-pondoh's production in Yogyakarta Province. On the other hand, the farmers got low price during great harvest season, because they did not have a bargaining position against the seller. This research formulated salacca-pondoh's business as a common condition in Sleman District in the form of system dynamics simulation. The factors influencing the farmers' low income during harvest season were also identified. The result showed several seasonal "pitfall" points that made farmer's income dropped "rock bottom" against the average value. This phenomenon may potentially make the farmers avoid planting salacca-pondoh and switch to more profitable fruit instead. Product diversification, either vertical or horizontal can be a step to increase the income of the farmers and intensify the economic activity in Sleman District by allocating some of the fruit and its waste to be diversified and converted into profitable derivative products. On the other side, the government can give price subsidy and market priority during high harvest season while the fruit is flooding the market to give the safety net for the price to not drop below farmer margin.
\end{abstract}

Keywords: Agriculture, salacca-pondoh, simulation, system dynamic.

\section{Introduction}

The Central Bureau of Statistics (BPS) of Yogyakarta Province (DIY) [1] stated that the agriculture contributed the second largest Gross Regional Domestic Product (GRDP) after manufacturing within 2013 to 2016 by $10.67 \%$ and the growth rate of GRDP reached $2 \%$ p.a. Sleman District has always been the most significant contribution to GRDP of DIY Province from 2013 to 2016 with an average of $27.44 \%$ from all districts/cities in Yogyakarta Province [1]. Production of horticultural crops in Sleman District dominated by salacca-pondoh, wherein the last five years (2012-2016), covers up to $94.05 \%$ (Figure 1) of total salacca production in Sleman District, the rest are for salacca-gading and regular salacca.

Salacca-pondoh, production in Sleman District on the year 2016 reached 73 kilotons, a rise of $4.33 \%$ from 2015, when the 2016 production covers up to $98 \%$ of total salacca-pondoh's production in Yogyakarta province [2]. Within a year, salacca plants have three harvesting times, the great harvest (November-January), small harvest (February-April) and mid-harvest (May-July).

\footnotetext{
${ }^{1}$ Faculty of Agricultural Technology, Agricultural Product Technology Department, Institut Pertanian STIPER, Jl. Nangka No. 2 Maguwoharjo, Yogyakarta 55282, Indonesia

${ }^{2}$ Faculty of Engineering, Mechanical and Industrial Engineering Department, Gadjah Mada University, Л. Grafika No. 2, Yogyakarta 55281, Indonesia.

Email: bimantiomp@instiperjogja.ac.id

* Corresponding author
}

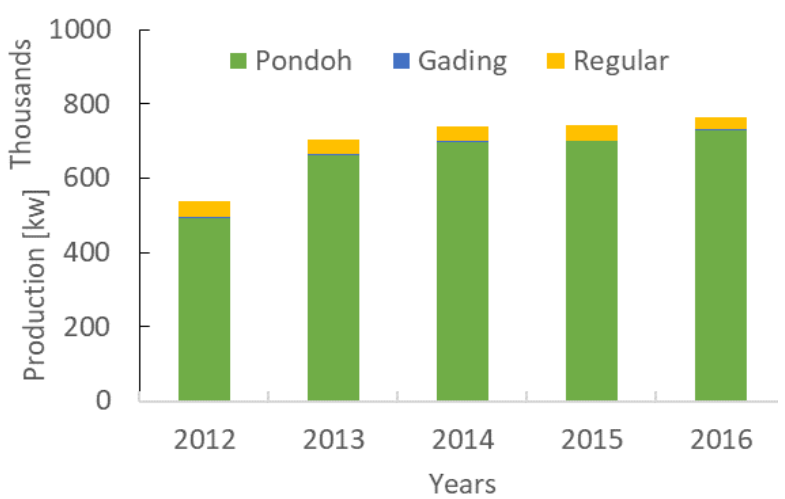

Figure 1. Production of salacca in Sleman District

Salacca-pondoh's farmers got a low price when the high harvest season came, where the selling price per kilogram dropped to less than Rp3000 (\$0.21), below the profit margin. This condition is due to abundant production during high harvest, and because of the nature of salacca-pondoh which deteriorates rapidly. Therefore most of them sell the fruits to nearest collecting traders. The farmer had a weak bargaining position so the profit margin of the farmers also low. The decreasing amount of productive land resulting from land conversion for construction or homeland and conversion of crops variety worsen the problem.

This research purpose is to formulate business as a general condition of salacca-pondoh in Sleman District in the form of system dynamic, so the factors that influence the low income of salacca-pondoh's farmers during great harvest time can be identified. This research tries to tackle the problem faced in 
salacca-pondoh's farm level through system dynamic simulation up to the secondary products effect and triple helix synergy of academic, business, and government.

\section{Methods}

\section{Salacca-pondoh}

Salacca-pondoh (salacca zalacca-pondoh) is a palmae family, spiked and sprouted, grow in the dense clump. Its plant height reaches $1.5-5 \mathrm{~m}$, stolonshaped stems in the ground, cylindrical with diameter 10-15 cm (Verheij and Coronel [3]). Salacca is non-climacteric fruits that can only be harvested if it is utterly ripe in the tree and it has a short lifespan (less than a week) due to the rapid degradation of bioactive materials (Ong and Law [4]). Nazaruddin and Kristiawati [5] stated that salacca-pondoh began to bear fruit 2-3 years from planting time and can begin to harvest 6-7 months since the occurrence of pollination.

The selling price fluctuated throughout the year depending on the number of crops at the time. The salacca-pondoh's selling price trends in Sleman District along the year 2016 showed in Figure 2 (BPS Kabupaten Sleman [2]).

Observations made by Faatiah et al. [6] indicate that the price of salacca-pondoh is influenced by the level of production and quality of the fruit itself. Farmers get the lowest price because the harvest volume is more than the trader need, so that price is generally set up by traders. The price is higher at the merchant level due to additional marketing costs. Farmers faced this dilemma every year. During the great harvest time, farmers need to expand the market into selling all the products, while mid and small harvest season they need to make a market priority.

Dewi [7] stated that $54.34 \%$ production of salaccapondoh is marketed through a local distribution channel. The competitiveness at the farm level is still low because it relies on collectors and retailers who can suppress the selling price during the great harvest. While for export distribution line it only covers $17.35 \%$ of the total production of the fruit.

Although the economic value of exported salaccapondoh give the highest selling price at the consumer level, it is enjoyed by the wholesalers and exporters. This channel only gives the farmer's share $17.50 \%$ only. It identifies that the government's turn to boost the quality of salacca-pondoh for export needs has yet given a significant impact on the income at the farm level.

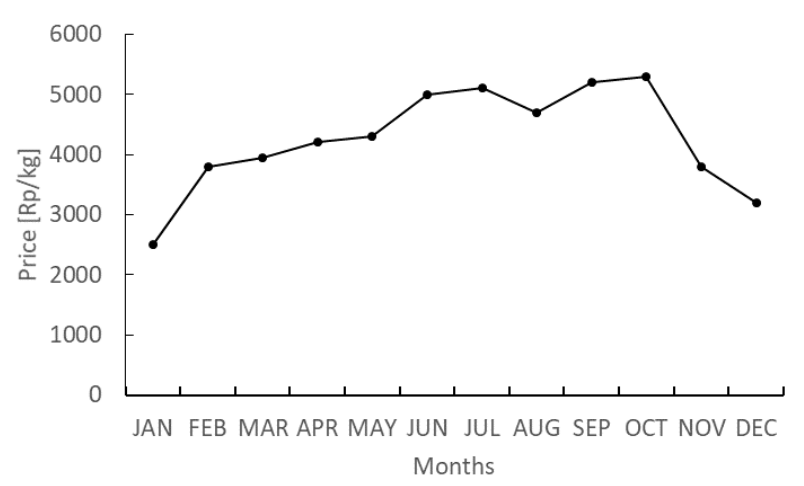

Figure 2. Salacca-pondoh's Prices Trend in Sleman District along 2016

The marketing pattern studied by Faatiah et al. [6] has described that farmers who produce salaccapondoh in small amounts due to the small area of his land will sell the fruits direct to the collectors, when farmers can produce large amounts of the fruits, will sell direct to merchant suppliers or retailers. During the great harvest season, farmers prefer to sell directly to merchant and suppliers although the price is low, this is due to transportation problems. Farmers do not need to find the buyers and do not have any risk if the fruit is unsold after harvesting, because the fruits will have its weight shrink and quality downgrade.

\section{System Dynamic}

System dynamic is a method used to study and manage feedback scheme from a complex system. It is used as a tool for analyzing and evaluating the consequences of a decision, either short-term or longterm and studying the interactions between components and behavior over time (Bouloiz et al. [8], Śpicar [9]). The system dynamic approach developed by Forrester [10] and better known as the descriptive causal model in which the validity is of vital importance. Altering the structure of the model resulted in modifying its behavior (Barlas [11]). The results verified and validated, both from the inner side and the comparison of the results with actual data (Barlas [11], Oliva [12]).

There are two steps in system dynamics modeling. The first one is qualitative modeling, where the ultimate goal is to form a causal loop diagram (CLD) that represents the interaction between variables that make up the system. The second one is quantitative modeling using stock-flow diagram (SFD), to formulate and simulate the model and to examine the effects of interaction between variables (Luna-Reyes and Andersen [13], Wolstenholme [14]).

Axella and Suryani [15] state that the use of system dynamic models in research has at least four advantages, namely: (1) Research can be carried across 
sectors and in a broader scope. (2) Can experiment with the system. (3) Able to determine the objectives of management and improvement activities. (4) Can predict behavior and state of the system in the future.

System Dynamic, like other modeling methods, have several limitations, as stated by Hirsch et al. [16]: (1) System Dynamic cannot represent a complex system, need some simplification and assumptions. (2) System Dynamic is useful in conditions and assumptions made based on the model. (3) Making a System Dynamic model requires skill and experience. (4) The System Dynamic functions as one of the supporting tools in decision making.

Previous research related to the use of a system dynamics model in agriculture has been done by Hasan et al. [17] formulated a model of soybean production as a self-sufficiency strategy involving variables such as productivity, land area, production demand, farmer income, import-tax and fertilizer quality, which in his research involves various scenarios including productivity, land, import cost regulation. The development of the cocoa industry with system dynamic simulation approach examined by Muis Hasibuan et al. [18] by focusing on the development of domestic downstream cocoa industry compared to an export policy of raw cocoa beans. The scenarios developed including increasing export duties, productivity, derivative capacity, and quality, abolishing export duties, and the combination of it. The result showed that the development of the processing industry tends slower compared to the development of farming which indicates that the downstream industry not well developed yet.

Blumberga et al. [19] in his research introduces system dynamic simulation based on biotechonomy (all economic activity derived from scientific and research activity focused on biotechnology) system as a step for design a policy for the efficient use of natural resources and development of researchbased sustainability economics. It is revealing that the procurement of a derivative business from natural raw material may provide an increase in the value of the product and income, which subsequently investment in research budget as a form of synergy with academics can produce new technologies for derivative business. The model developed is analogous to the form of "lego" that can be combined at various levels of needs (micro, meso, and macro).

Analysis of the agricultural system in the United States with system dynamic has performed by Walters et al. [20]. The research used qualitative and quantitative methods in developing and simulating models to obtain interaction results between the economic, environmental, and social issue of agricultural production with scenarios of land usage for agriculture and livestock.

In the case of local agricultural commodities, the system dynamic has been used as one of the research methods, as in the research conducted by Widodo and Rembulan [21] which examined shallot supply chain systems in Bantul District, DIY Province. Aminudin [22] reviews the resilience of the national potato supply. Kusnadi and Tinaprilla [23] formulated a system dynamics model for national rice selfsufficiency scenario. These studies examine the factors that influence the demand, production, price, and income of an agricultural commodity.

The business as usual condition is expected to be reviewed and compared to what extent the Academic-Business-Government synergy concept as various simulation scenarios, with the help of system dynamic simulation method. The approach used in this study was carried using a system dynamic model approach. This approach used because it is suitable for analyzing and designing a policy characterized by interdependence, mutual interaction, information feedback, and a circle of causal relationships (Chen and Jeng [24]). The results of this simulation can provide a broader picture of results compared to statistical methods, especially in problems that require forecasting (Lyneis [25]).

\section{Experiment apparatus}

To achieve the purpose, Vensim PLE software developed by Ventana System is used to capture the interaction and to model various complex variables such as social, environment, technique, and economy. This software is useful as a comparative analysis tool [26]. Validation of input and output variable and the result of the research is done by using SPSS23 software as a statistical test and data documentation tool.

\section{Technique}

The method conducted in this research is descriptive-simulation method, which is a form of research based on data collected during the systematic study of the facts and properties of the object by combining relationships among variables involved in it, interpreted into the form system dynamic simulation based on the theories and literature. This method aims to provide a clear picture of the problem. Data collection is done through direct observation to salacca-pondoh's industry in Sleman District, interview with related parties such as salacca-pondoh's farmer's association and relative from the Ministry of Agriculture in Sleman District. 


\section{Results and Discussions}

Submodel Business as Usual (BaU) provides an overview of the salacca-pondoh's business system with the fruit as the main product. This model describes the factors that influence the amount of fruit production and the sale of the fruit. Revenue from sales on the market depends on the volume and price of the product, where profits earned after incomes reduced by production costs. Production cost generally consists of a fixed cost that is independent of production capacity and variable cost that are dependent on the production capacity. Farmers' income will be taxed in the form of land and building tax (PBB) based on the fruit's plantation area, PBB paid to the government. The amount of tax is directly proportional to the size of the harvest area where the tax paid will affect the profit earned by the farmers.

Sale of the products currently includes not only for local markets, but also abroad with variables for export markets analogous to products for the local market. The result of CLD for $\mathrm{BaU}$ can be seen in Figure 3, where the final form of the CLD submodel $\mathrm{BaU}$ complemented by factors that affect the harvest area, total harvest, and the possibility of waste produced from salacca crops such as rotten skin, seeds, and salacca meat. A CLD consists of variables that connected by an arrow which symbolizes a causal relationship between the variables connected. Each causal relationship characterized by a polarity, either positive (+) or negative (-) which indicates how the relationship between a dependent variable and independent variable (Steman [27]).
Causal loop diagram from Figure 3 then transformed into SFD as in Figure 4, where profit for farmers is obtained from the sale of the fruits, both local and export, reduced by cost for harvest and waste processing resulting from rotten fruit bark and crop failure. The result is still reduced again by the Land and Building Tax (PBB) paid to the government. The total profit obtained divided by the number of salacca-pondoh's farmers in Sleman (fraction of the number of farmers in Sleman), by taking the assumption that all salacca-pondoh is sold, it can obtain the income value for each farmer of salacca-pondoh in Sleman District.

\section{Total Fruit Production}

The simulation results for the "Total fruit production" variables are validated with actual data obtained from Horticultural Statistics issued by the Central Bureau of Statistics (BPS) of DIY Province. The result of t-test shows the significance value between simulation result and actual data is 0.607 ; this is bigger than a (0.05) for a 95\% confidence level. So there is no significant difference between simulation result and actual data. As seen in Figure 5, the simulation result data is in line with the actual data. Where total production of salacca-pondoh which exceeds 10 million $\mathrm{kg}$ at 3 points in a specific time lag during the simulation time-span. A large amount of production shows the increasing behavior of salacca-pondoh's production, especially during the great harvesting conditions at the end and the beginning of the calendar year.

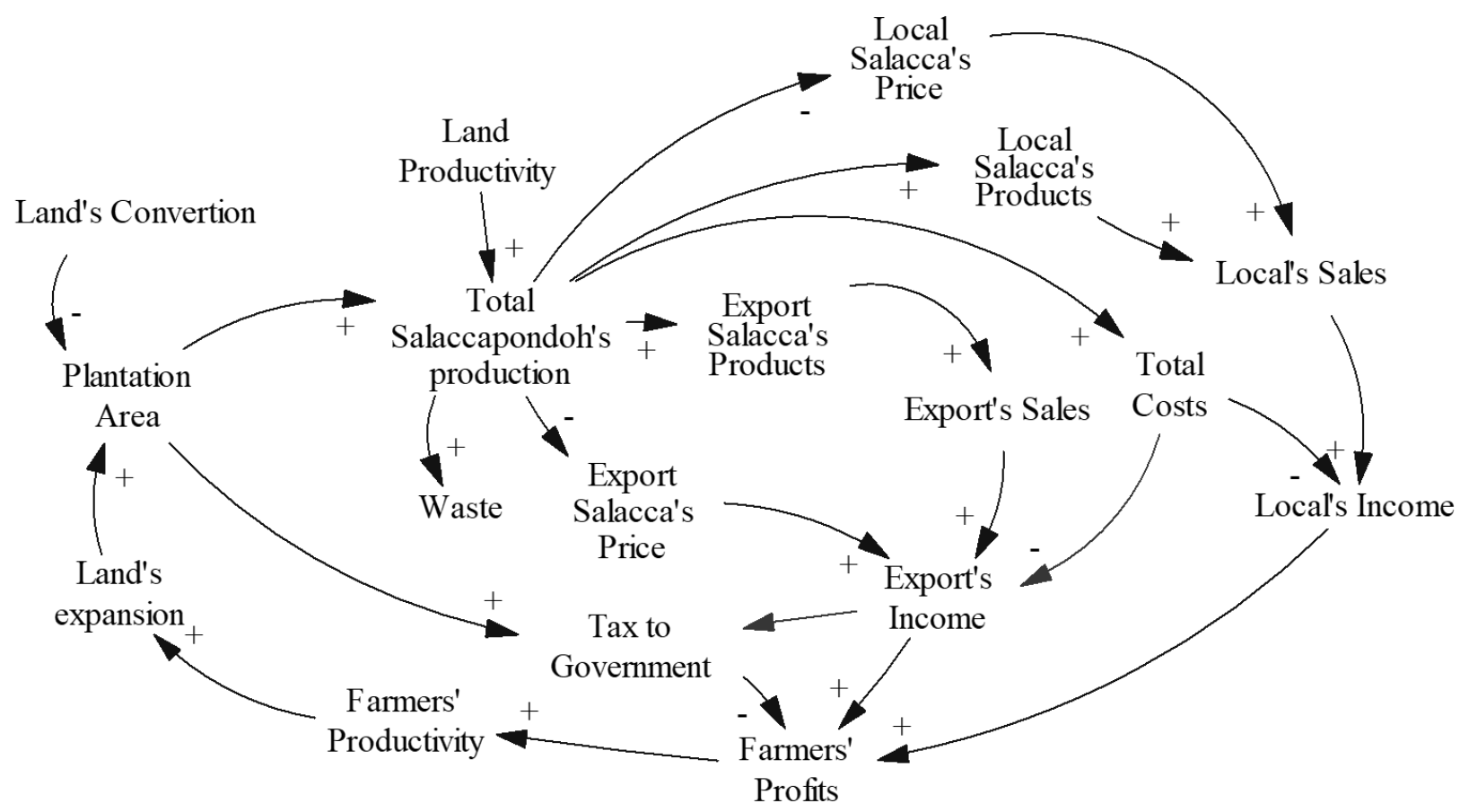

Figure. 3 Causal loop diagrams for Salacca-pondoh's Business as Usual 


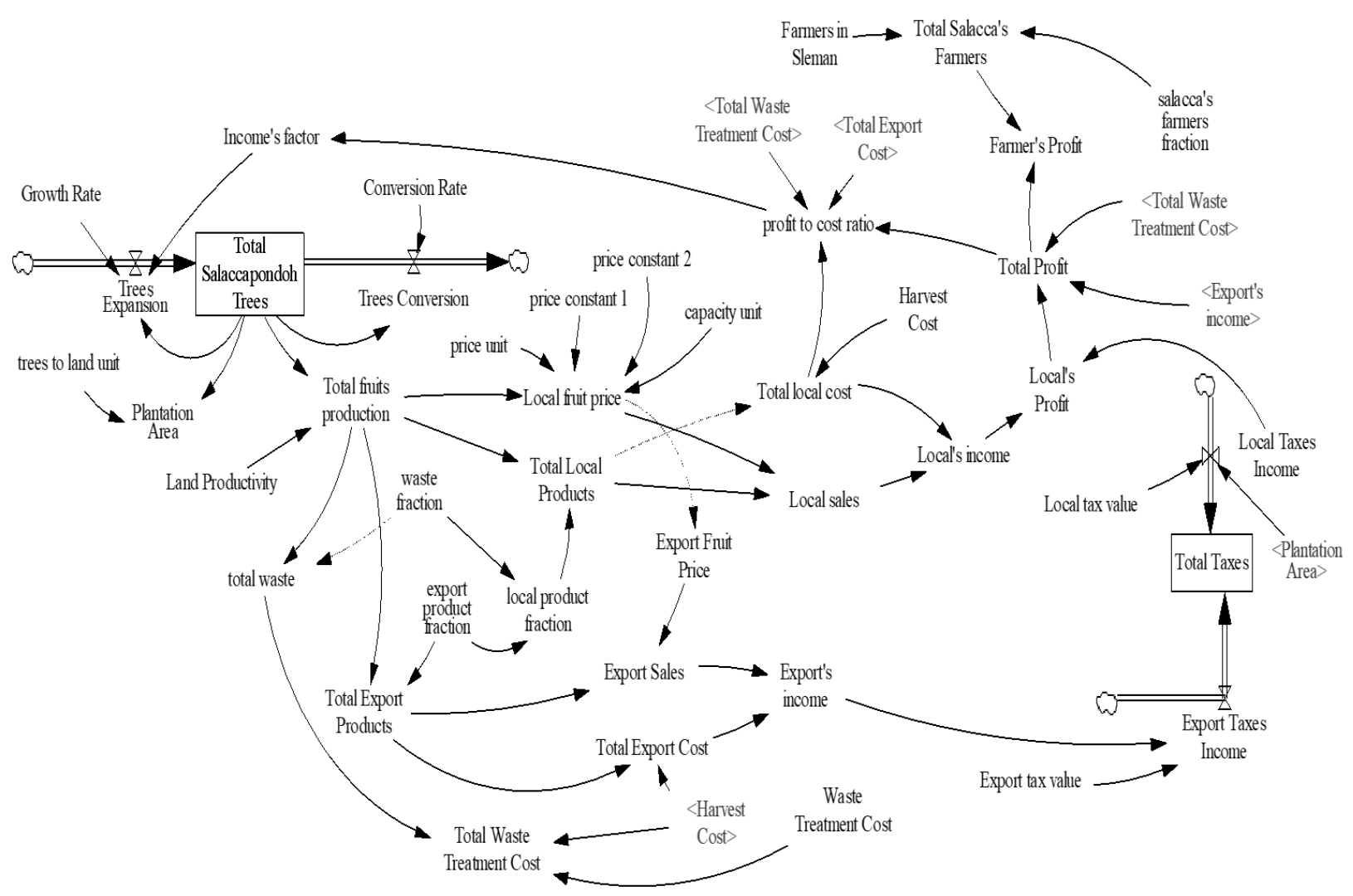

Figure 4. Stock and flow diagram for Salacca-pondoh's Business as Usual

Based on the simulation results, it can be seen the cause's tree for "Total fruit production" variables, Figure 6 shows the total fruit production influenced by the number of salacca-pondoh's trees and productivity of the plantation land. While the number of trees itself influenced by the number of procurements of the new trees (expansion) and the number lasted either because of its lifetime or converted to other types of plants.

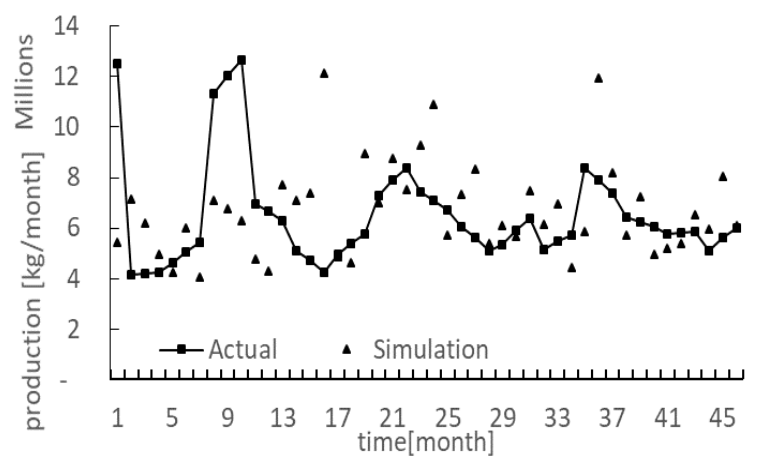

Figure 5. Comparison of Salacca-pondoh's production

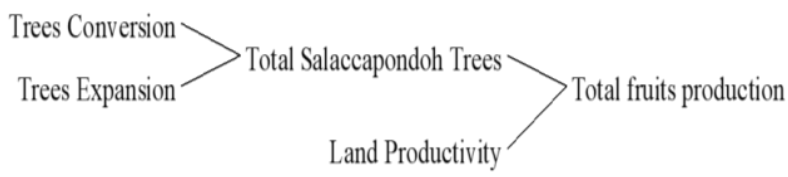

Figure 6. Cause's Tree for "Total fruit production" variable

\section{Local Fruit Price}

The simulation results for "Local fruit price" variable is validated with actual data obtained by monthly average salacca-pondoh's producer price in Sleman

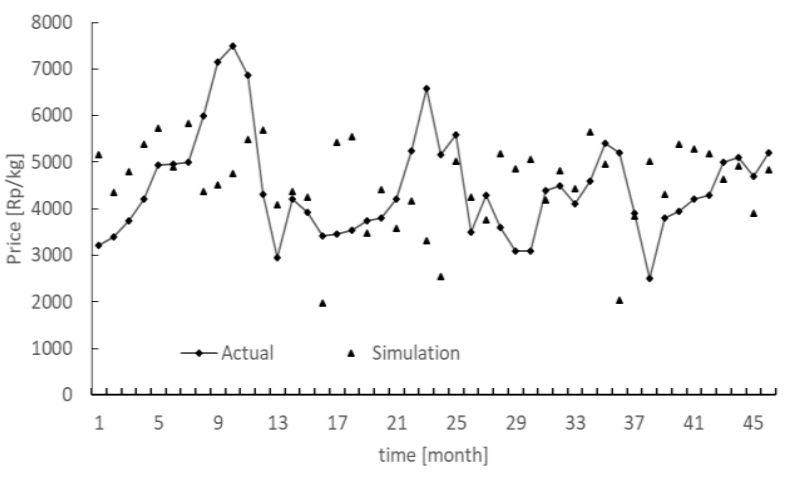

Figure 7. Comparison of Salacca-pondoh's price in Local Market

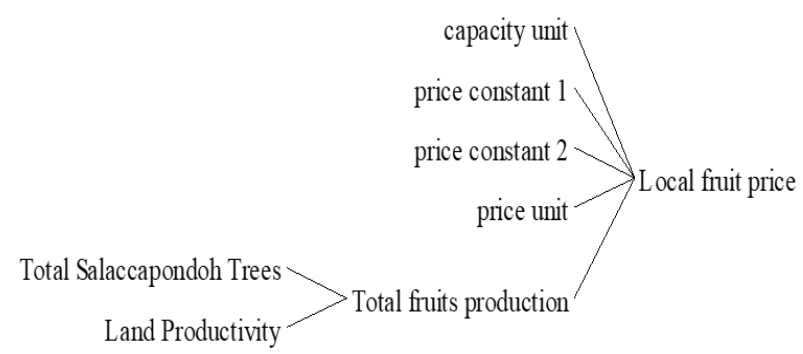

Figure 8. Cause's Tree for "Local fruit price" variable 


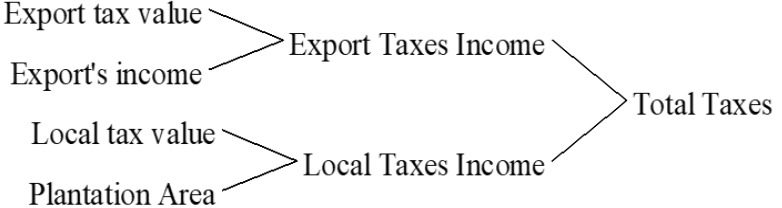

Figure 9 Cause tree diagram for the total taxes paid to the government

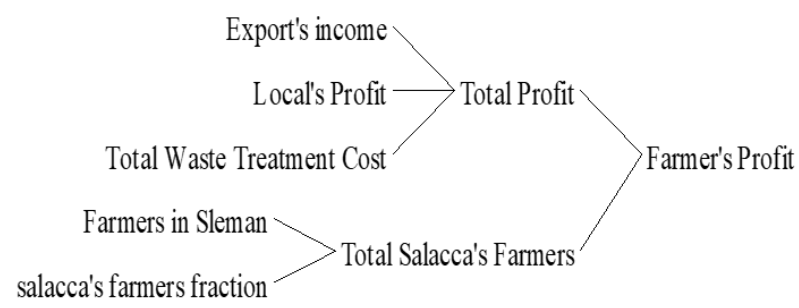

Figure 10 Cause tree diagram of the farmer's profit

District issued by the Central Bureau of Statistics (BPS) of Sleman District. The result of t-test shows that the significance value between simulation result and actual data is 0.693 , higher than a value of 0.05 for $95 \%$ confidence level. So, there is no significant difference between simulation result and actual data (Figure 7).

\section{Total Tax}

In the simulation, the government total taxes are coming from two directions: local taxes derived from the payment of land and building tax (PBB) based on the area of salacca-pondoh's plantation and export tax based on export business activity undertaken by exporters of salacca-pondoh.

The amount of PBB is paid to Sleman District Regulation Number 11 the Year 2012 About Land Tax and Rural and Urban Buildings straight with the existing salacca-pondoh's plantation area. Whereas for export tax, the amount of its value refers to the Regulation of the Ministry of Finance of the Republic of Indonesia Number 34/Pmk.010/2017 about Income Tax Collection Article 22 in connection with Payment of Delivery of Goods and Activities in Import or Business in Other Fields. Based on the simulation results, the total taxes obtained at the end of time-span is $\operatorname{Rp~} 17,918,941,184(\$ 1,254$, 325.88).

\section{Farmer's Profit}

The "Farmer's profit" variable represents the income earned from the sales of the fruits for each farmer. Figure 10 shows the variables that affect the value of "Farmer's profit" variable, which derived from the total business profit from the fruits sales divided by the number of salacca-pondoh's farmers in Sleman District. The "Total Profit" variable itself consists of the total income from salacca-pondoh sales in either local market or export after deducting the expenses incurred to handle the waste of the fruit (rotten or harvest failure).

The pitfall occurs seasonally over the specific time during great harvesting season around the end and beginning of the year, which occurs at the 15th, 23rd, and 35th-month time-span. The value of each time periods are $\operatorname{Rp~1,160,248~(\$ 81.22),~Rp1,404,709~}$ (\$98.33), and Rp3,187,685 (\$223.14) respectively.

This phenomenon confirmed by results of the interviews with the board of salacca-pondoh farmers association in Sleman District, where farmers tend to follow to cultivate the crop that has high profit during certain times. In the simulation, represented as a "profit-cost ratio" variable that will be a constant affecting the rise/fall of the number of new salaccapondoh tress.

Figure 12 showed the result of sensitivity analysis from $\mathrm{BaU}$ simulation developed in this research. The analysis performed for two key variables, fruit production and fruit price, any change for those variables compared against farmer's income variable showed which variable had more impact on the income. Fruit production and fruit price variables had run to the other side of each other. While fruit production had a negative linear relationship against farmer's income, fruit price, on the other hand, had a positive linear relationship against farmer's income.

Excessive fruit production did not give good impact for farmer's income due to saturation of the market made the price to be dropped in advance to sale the fruit as much as possible. The natural condition of salacca-pondoh that only last for seven days before it ripen made this condition even worse.

The academia and the government need to be present to solve this annual problem. Research and technology to convert the fruit into a derivative product that can increase its value and long lasted its lifetime needed. The government can give price subsidy and market priority during great harvest season while the fruit is flooding the market in order to give the safety net for the price for not to be a drop below farmer margin.

\section{Conclusion}

The results of the simulation revealed there are seasonal "pitfalls" on the farmer's profit that makes its value drop far below the average. This low-income level has the potential to make the farmers did not replant the salacca-pondoh and then switch to other fruits that are more profitable, this phenomenon will have implications to reduce the number of salaccapondoh's trees because of the conversion of crop and the plantation land. 


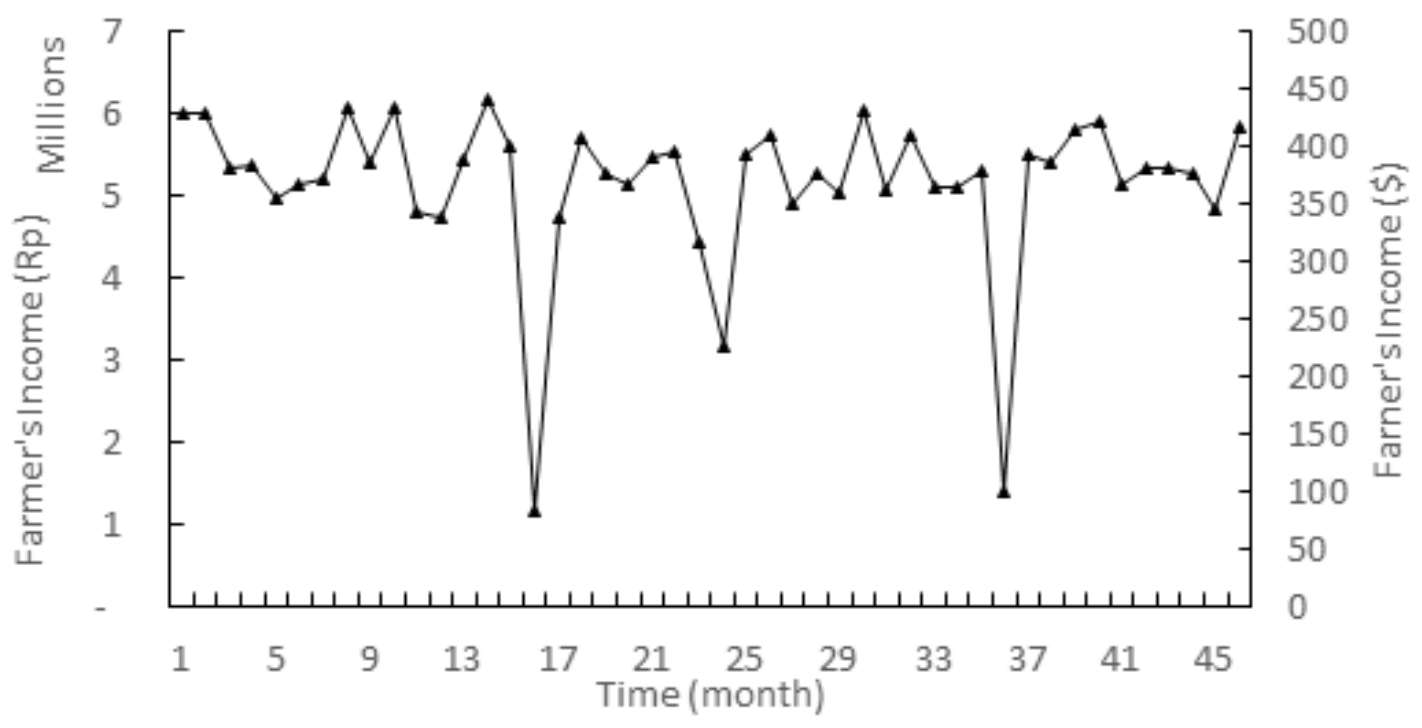

Figure 11 Simulation result for the farmer's profit

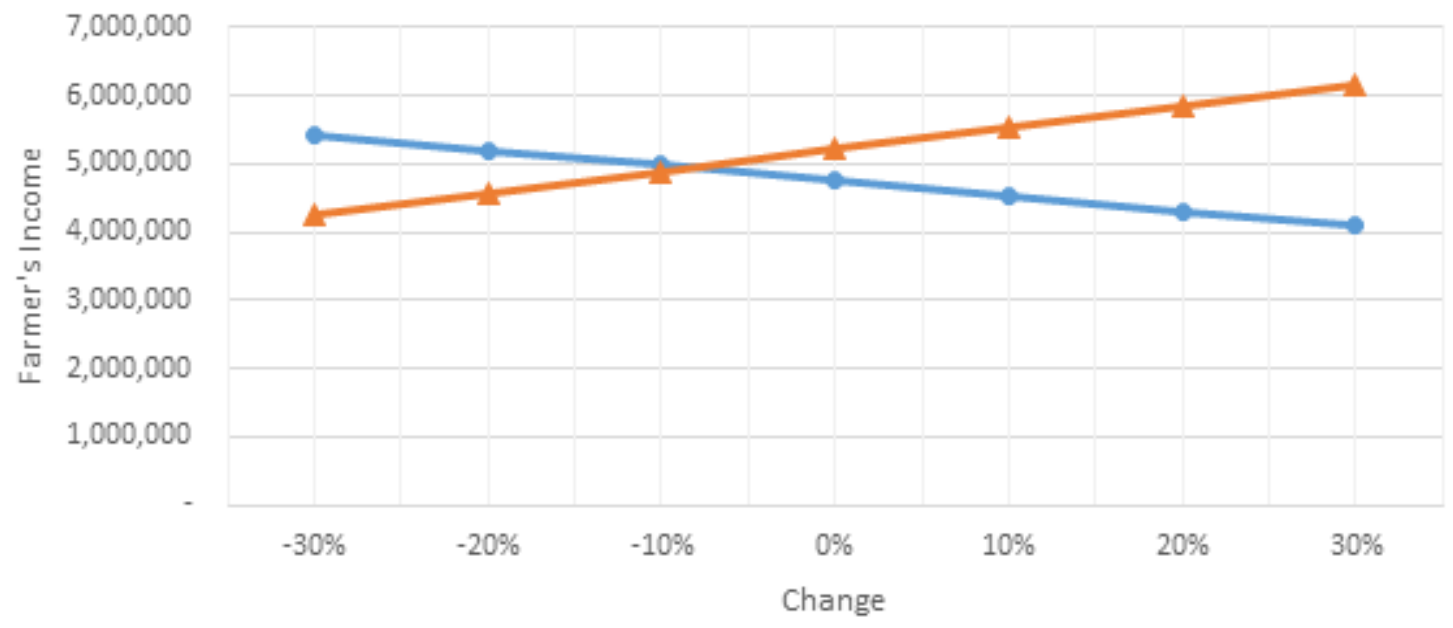

—Fruit Production $\quad$ Fruit Price

Figure 12. Sensitivity analysis for business as usual simulation

Therefore, it should be efforts to increase the value of salacca-pondoh, especially when the price drop. One of the solutions is to process the fruits into processed derivative products that have higher economic value and to provide additional income for the farmers. Academia are expected to come up with a solution. Besides, these processed products will have a longer life with much higher economic value than fresh salacca-pondoh fruit and more significant market share. This solution can be looked as vertical diversification and can be developed in Sleman District.

The proceeds from this business tax utilized as government's aid either in the form of business capital subsidy or to set a minimum price of salaccapondoh during the great harvest season.
From an environmental point of view, derivative products that use raw materials in the form of waste from the fruit's products can reduce the burden to the environment and reduce the cost for treatment (Blumberga et al. [19]).

Further study for the effect of derivative product sales, government's tax allocation, and academic research innovation is currently on-going progress for the author's next research.

\section{References}

1. BPS Provinsi D.I. Yogyakarta, Daerah Istimewa Yogyakarta dalam Angka 2017. Yogyakarta: BPS Provinsi D.I. Yogyakarta, 2017, p. 520. 
2. BPS Kabupaten Sleman, Kabupaten Sleman dalam Angka 2017, Sleman: BPS Kabupaten Sleman, 2017, p. 443.

3. Verheij E.M., and Coronel, R E, Edible Fruits and Nuts, Wageningen, Pudoc, 1991.

4. Ong, S. P, and Law, C. L., Mathematical Modelling of Thin Layer Drying of Salak, Journal of Applied Science,9(17), 2009, pp. 3048-3054.

5. Nazaruddin, and Kristiawati R., 18 Varietas Salak, Penebar Swadaya, Depok, 1992.

6. Faatiah, M. B, Utama, A. G., and Nordian, M. Potret Pertanian Salak di Sleman, sebuah Hasil Pengamatan Lapangan di Desa Trumpon, Laporan Penelitian, Bandung, 2013.

7. Dewi, A., Analisis Tataniaga Salak Pondoh di Desa Wonokerto, Kecamatan Turi, Kabupaten Sleman, Institut Pertanian Bogor, 2014.

8. Bouloiz, H., Garbolino, E., Tkiouat, M., and Guarnieri, F., A System Dynamics Model for Behavioral Analysis of Safety Conditions in a Chemical Storage Unit, Safety Science, 58, 2013, pp. 32-40.

9. Spicar. R., System Dynamics Archetypes in Capacity Planning. Procedia Engineering, 69, pp. 1350-1355.

10. Forrester, J.W. Industrial Dynamics, Journal of the Operational Research Sociecty, 48(10), 1997, pp.1037-1041

11. Barlas Y., Formal Aspects of Model Validity and Validation in System Dynamics, System Dynamic Review, 12(3), 1996, pp. 183-210.

12. Oliva, R., Empirical Validation of a Dynamic Hypothesis, Proceedings of the 1996 International System Dynamics Conference System Dynamics Society, Cambridge, MA. 1996. pp. 405-408.

13. Luna-Reyes, L.F, and Andersen, D.L., Collecting and Analyzing Qualitative Data for System Dynamics: Methods and Models, System Dynamic Review, 19(4), 2003, pp. 271-296.

14. Wolstenholme, E.F, System Enquiry: A System Dynamic Approach, John Wiley \& Sons, 1990.

15. Axella, O., and Suryani, E., Aplikasi Model Sistem Dinamik untuk Menganalisis Permintaan dan Ketersediaan Listrik Sektor Industri (Studi Kasus: Jawa Timur), Jurnal Teknik, ITS, 1, 2012, pp. 339-344.

16. Hirsch, G.B., Levine, R., Miller, R.L., Using System Dynamics Modeling to Understand the
Impact of Social Change Initiatives, American Journal of Community Psychology, 39(3-4), 2007, pp. 239-253.

17. Hasan, N., Suryani, E., and Hendrawan, R. Analysis of Soybean Production and Demand to Develop Strategic Policy of Food Self Sufficiency, A System Dynamics Framework, Procedia Computer Science, 72, 2015, pp. 605-612.

18. Hasibuan, A.M., Nurmalina, R., and Wahyudi, A., Policy Analysis of Cocoa Downstream Industry Development: A System Dynamic Approach, Informatika Pertanian, 21(2), 2012,pp. 59-70.

19. Blumberga, A., Bazbauers, G., Davidsen, P., Blumberga, D., Gravelsins, A., and Prodanuks, T, System Dynamics Model of a Biotechonomy, Journal of Cleaner Produdction, 172, 2018, pp. 4018-4032.

20. Walters, J.P., Archer, D.W., Sassenrath, G.F., Hendrickson, J.R., Hanson, J.D., Halloran, J.M., Vadas, P., and Alarcon, V.J, Exploring Agricultural Production Systems and Their Fundamental Components with System Dynamics Modelling, Ecological Modelling, 333, 2016,pp. 51-65.

21. Widodo, K.H., and Rembulan, D., Basic Supply Chain Bawang Merah Daerah Istimewa Yogyakarta dari Perspektif Sistem Dinamis. INASEA, 11(2), 2010, pp. 87-95.

22. Aminudin, M., Simulasi Model Sistem Dinamis Rantai Pasok Kentang dalam Upaya Ketahanan Pangan Nasional, Univesitas Islam Negeri Syarif Hidayatullah, 2014.

23. Kusnadi, N., and Tinaprilla, N., Indonesia Rice Supply and Demand Dynamic Model, AFBE Journal,4(2), 2011, pp. 502-20.

24. Chen, Y. T., and Jeng, B., Yet Another Representation for System Dynamics Models, and Its Advantages, Proceding of $20^{\text {th }}$ System Dynamics Conference, Palermo, 2002.

25. Lyneis, J.M., System Dynamics for Market Forecasting and Structural Analysis, System Dynamic Review, 16(1), 2000, pp. 3-25.

26. Vensim, Vensim PLE and Vensim PLE Plus User's Guide 4th edition., Ventana System Inc., USA; 1999.

27. Sterman, J. D., Business Dynamics, System Thinking and Modeling for A Complex World, McGraw-Hill Educ Bost. 2000, p. 982. 